\title{
Perlindungan Konsumen Terhadap Makanan Pangan Industri Rumah Tangga
}

\author{
Ernawati \\ Dosen Fakultas Hukum Universitas Muhammadiyah Buton
}

\begin{abstract}
Consumers have the freedom to determine the type and quality of the goods/services in accordance with their needs. Food safety, quality problems and the impact of irregularities, as well as the strengths, weaknesses, opportunities and threats in the development of food industry quality system is a shared responsibility as the consumer protection efforts. The method in this research using qualitative methods. The research results showed that consumer protection conducted by government agencies and other institutions in the following way i.e. perform monitoring of food products by giving the number of the PIRT against businessmen who are qualified and have previously received counseling about the food products that may be released, as well as to provide warning and withdrawal of products that contain a positive dye textiles. The efforts made by the North Buton Regency POM Halls namely collaborates with government agencies and Institutions Consumers North Buton Regency to do surveillance, sampling and testing, guidance products. Trade a proven violation reported to the District Health Office of North Buton for follow up. Restricting factors for the Government and Consumers North Buton Regency in coping with a circulation of foods that contain colouring substances in textiles, namely budget constraints to organise activities agenda so that there are no activities were carried out, bureaucratic system which is still so convoluted follow-up to businessmen.
\end{abstract}

\section{Keyword: Consumer Protection, Food, Food Industry, Household}

\section{A. PENDAHULUAN}

Salah satu pengaruh globalisasi yang menyebabkan konsumen diberikan banyak pilihan, pelaku usaha semakin dipacu untuk memproduksi barang atau jasa yang sesuai kebutuhan dan diminati oleh masyarakat, namun apakah sudah memperhatikan kualitas bahan produksi yang benar-benar dapat dipertanggung jawabkan, selain itu pelayanan kepada konsumen apakah sudah optimal.

Walaupun teknik pengolahan makanan telah berkembang pesat, namun makanan yang di konsumsi juga harus aman bagi keselamatan dan kesehatan jasmani maupun rohani. Makanan yang akan didistribusikan harus memenuhi persyaratan kualitas, 
penampilan, dan cita rasa. Keamanan pangan di Indonesia masih jauh dari keadaan aman, konsumen pada umumnya belum memperdulikan atau belum memiliki kesadaran tentang keamanan makanan yang mereka konsumsi, sehingga belum banyak menuntut produsen untuk menghasilkan produk makanan yang aman.

Telah terjadi penyalahgunaan pemakaian pewarna untuk bahan makanan. Sekarang ini, pewarna untuk makanan menggunakan pewarna untuk tekstil. Banyak produsen yang menggunakan pewarna tekstil untuk berbagai produk makanan. Berkembangnya industi tekstil di Indonesia menyebabkan pewarna tekstil menjadi murah dan mudah didapatkan yang akhirnya pewarna tekstil ini disalahgunakan pemanfaatannya oleh kalangan produsen makanan pewarna tekstil yang banyak digunakan oleh produsen makanan.

Pewarna tekstil adalah pewarna sintetis yang digunakan untuk membuat makanan berwarna merah terang. Pewarna tekstil sebenarnya telah dilarang penggunaanya melalui Keputusan Direktur Jendral Pengawasan Obat dan Makanan Departemen Kesehatan Republik Indonesia Nomor 00386/C/SK/II/90 Tentang Perubahan Lampiran Peraturan Menteri Kesehatan Nomor 239/Menkes/Per/V/85 Tentang Zat Warna Tertentu Yang Dinyatakan Sebagai Bahan Berbahaya. Penggunaan pewarna tekstil pada makanan akan mengakibatkan gangguan fungsi hati bahkan apabila dipergunakan dalam jangka waktu yang lama akan mengakibatkan kanker hati. Selain itu pewarna tekstil dapat mengakibatkan iritasi pada saluran nafas, kulit, mata, dan infeksi pada saluran pencernaan.

Peredaran pangan yang mengandung bahan berbahaya perlu diwaspadai oleh konsumen karena belum adanya perlindungan yang maksimal. Peredaran pangan yang 
tidak memenuhi standar kesehatan tersebut pada umumnya disebabkan keinginan produsen agar mendapat keuntungan sebanyak-banyaknya dengan mengesampingkan keselamatan konsumen. Sementara itu pengetahuan konsumen masih belum memadai untuk dapat memilih dan memakai produk yang tepat, benar, dan aman. Berdasarkan data yang didapat dari Dinas Kesehatan Kabupaten Buton Utara, di Kabupaten Buton Utara pada Tahun 2015 masih terdapat pelaku usaha yang memakai pewarna makanan, serta pengawet makanan berbahaya, di antaranya adalah Jipang Warna, onde-onde dan snack yang di jual di Dinas Kesehatan.

Konsumen memiliki kebebasan untuk menentukan jenis dan kualitas barang/jasa sesuai dengan kebutuhannya. Keamanan pangan, masalah dan dampak penyimpangan mutu, serta kekuatan, kelemahan, peluang dan ancaman dalam pengembangan sistem mutu industri pangan merupakan tanggung jawab bersama sebagai upaya perlindungan konsumen. Hal ini berdasarkan Pasal 4 ayat (1) Undang-Undang Republik Indonesia Nomor 8 Tahun 1999 tentang Perlindungan Konsumen yaitu "hak konsumen adalah hak atas kenyamanan, keamanan dan keselamatan dalam mengkonsumsi barang dan/atau jasa" dan Pasal 4 ayat (3) yang berbunyi "hak atas informasi yang benar, jelas, dan jujur mengenai kondisi dan jaminan barang dan/atau jasa". Sedangkan pengawasan terhadap penyelenggaraan perlindungan konsumen sesuai Pasal 30 Undang -Undang Nomor 8 Tahun 1999 tentang Perlindungan Konsumen yang berbunyi "pengawasan terhadap penyelenggaraan perlindungan konsumen, serta penerapan ketentuan peraturan perundang-undangannya diselenggarakan oleh pemerintah, masyarakat, dan lembaga perlindungan konsumen swadaya masyarakat". 
Atas dasar kondisi sebagaimana dipaparkan diatas, perlu upaya pemberdayaan konsumen melalui pembentukan undang-undang yang dapat melindungi kepentingan konsumen secara integrative dan komprehensif serta dapat diterapkan secara efektif di masyarakat

\section{B. METODE PENELITIAN}

Metode dalam penelitian ini menggunakan metode kualitatif, yaitu prosedur penelitian yang menghasilkan data deskriptif yang berupa kata-kata tertulis atau lisan dari orang-orang dan perilaku yang diamati (Moleong, 2004:4). Lokasi menunjukkan tempat dimana penelitian dilakukan dalam rangka mempertanggungjawabkan data yang diperoleh. Lokasi yang dipilih dalam penelitian ini adalah di Kabupaten Buton Utara khususnya pada Dinas Kesehatan Kabupaten Buton Utara. Data yang digunakan dalam penelitian ini dibagi menjadi 2 data, yaitu Data Primer : Data yang diperoleh secara langsung melalui sumber pertama, "yakni perilaku warga masyarakat, melalui penelitian” ( Soerjono Soekanto, 2005 : 12 ). Data Sekunder: Yaitu data yang diperoleh dari kepustakaan yang terdiri dari literatur, peraturan perundang-undangan yang berlaku serta relevan dengan masalah yang di teliti, karya tulis para ahli, kamus dan lain-lain. Dalam pengumpulan data ini peneliti menggunakan data primer sebagai data utama dan data sekunder sebagai data dukungan penguat dari data utama. Data yang terkumpul banyak sekali dan terdiri dari catatan lapangan, gambar, foto, dokumen berupa laporan, struktur organisasi, artikel, tape recorder dan sebagainya. Setelah data dari lapangan terkumpul dengan menggunakan metode pengumpulan data di atas, maka peneliti akan mengolah dan menganalisis data tersebut dengan menggunakan analisis secara deskriptif-kualitatif, tanpa menggunakan teknik kuantitatif. 


\section{PEMBAHASAN DAN ANALISIS}

\section{Pengawasan Hak Konsumen Atas Keamanan Dalam Mengkonsumsi Makanan} Olahan Industri Rumah Tangga Berdasarkan Undang -Undang Nomor 8 Tahun 1999 Tentang Perlindungan Konsumen

Berdasarkan hasil penelitian penulis maka sesuai amanat Undang -Undang Nomor 8 Tahun 1999 tentang Perlindungan Konsumen dikaitkan dengan hak konsumen mendapatkan kenyamanan, keamanan dan keselamatan dalam mengkonsumsi barang dan/atau jasa; hak mendapatkan informasi yang benar, jelas dan jujur mengenai kondisi dan jaminan barang dan/atau jasa; serta hak mendapatkan pembinaan dan pendidikan konsumen. Pangan merupakan kebutuhan dasar manusia yang juga merupakan komoditas, memerlukan dukungan sistem pangan yang etis, jujur, \& bertanggung jawab sehingga terjangkau oleh masyarakat. Pangan dalam bentuk makanan \& minuman adalah salah satu kebutuhan pokok manusia yang diperlukan untuk hidup, tumbuh, berkembang biak, \& reproduksi. Dalam pasal 1 Undang-Undang Nomor 7 Tahun 1996 tentang Pangan, disebutkan bahwa "Pangan adalah segala sesuatu yang berasal dari sumber hayati \& air, baik yang diolah, yang diperuntukkan sebagai makanan atau minuman bagi konsumsi manusia, termasuk bahan tambahan pangan, bahan baku pangan, \& bahan lain yang digunakan dalam proses penyiapan, pengolahan, \& atau pembuatan makanan atau minuman". Kemudian telah disebutkan mengenai hak dan kewajiban konsumen dalam Undang-Undang Nomor 8 Tahun 1999 tentang Perlindungan Konsumen dalam Pasal 4 dan Pasal 5 yakni sebagai berikut:

Kesembilan hak konsumen tersebut yang makin perlu secara kontinu disosialisasikan kembali oleh pebisnis bersama media, YLKI, penegak hukum, pengacara, 
dan pengamat, terutama di daerah, agar tetap sadar adanya hak-hak konsumen yang terhitung "demand side" dari perekonomian, yakni masyarakat konsumen dan umum. Makin sadar akan hak dan kewajiban kedua pihak, "supply side" dan "demand side", maka semakin berbudaya kehidupan bangsa ini. Sebagai bahan pembanding, yang pernah dijadikan referensi Lembaga Konsumen negeri ini, adalah hak-hak dasar umum yang diakui secara internasional.

Oleh karena sebab kepraktisannya, banyak orang yang senang mengkonsumsi makanan kemasan. Akan tetapi, kita pun tetap harus memperhatikan komposisi dan kandungan pada makanan jenis ini supaya kandungan gizi yang diasup tetap sesuai secara kebutuhan. Perubahan atas Peraturan Kepala BPOM tahun 2005 tentang Pedoman Pencantuman Informasi Nilai Gizi pada Label Pangan telah dikeluarkan oleh Kepala Badan Pengawas Obat dan Makanan (BPOM) RI tahun 2011. Peraturan ini berbunyi, “Setiap orang yang memproduksi pangan olahan yang mengandung gula, garam, dan lemak untuk diperdagangkan, wajib memuat informasi kandungan gula, garam, dan lemak, serta pesan kesehatan pada label pangan."

Disertai pula pernyataan bahwa pangan tersebut mengandung vitamin, mineral, dan atau zat gizi lainnya yang ditambahkan, dan juga dipersyaratkan berdasarkan ketentuan peraturan perundang-undangan yang berlaku di bidang mutu dan gizi pangan, produsen wajib menambahkan vitamin, mineral dan atau zat gizi lainnya. Maka, pada intinya informasi yang wajib dicantumkan pada label, antara lain takaran saji, jumlah sajian per kemasan, dan catatan kaki. Sedangkan zat gizi yang wajib dicantumkan antara lain energi total, lemak total, protein, karbohidrat total, dan natrium. 
Formalin sangat mudah diserap oleh tubuh melalui saluran pernafasan dan pencernaan. Penggunaan formalin dalam jangka panjang dapat berakibat buruk pada organ tubuh. Karena beracun, pada kemasan formalin diberi label yang bertuliskan "Jangan menggunakan formalin untuk mengawetkan pangan seperti mie dan tahu".

Kasus Penyalahgunaan Zat Berbahaya bagi Produk olahan di Kabupaten Buton Utara pada Tahun 2015 masih terdapat pelaku usaha yang memakai pewarna makanan, serta pengawet makanan berbahaya, di antaranya adalah Jipang Warna, onde-onde dan snack yang di jual di Dinas Kesehatan. Data nasional yang dirangkum BPOM selama 4 tahun terakhir juga menjelaskan, bahwa industri jasa produk olahan pabrik kecil dan produk makanan rumah tangga memberikan kontribusi yang paling besar (31\%) dibandingkan dengan pangan olahan (20\%); jajanan (13\%) dan lain-lain (5\%).

Hasil kajian dan analisa Dinas Kesehatan Kabupaten Buton Utara juga tidak menemukan adanya penggunaan bahan terlarang dalam produk makanan. Namun pelaku usaha masih kurang memperhatikan mengenai masalah kehigienisan atau kebersihan produk olahannya. Maka hasil penelitian penulis menunjukkan bahwa dalam hal pelaksanaan perlindungan hak konsumen atas informasi dan keamanan dalam mengkonsumsi makanan yang mengandung zat pewarna tekstil berdasarkan UndangUndang Nomor 8 Tahun 1999 Tentang Perlindungan Konsumen yang dilakukan oleh instansi pemerintah dan lembaga lainnya di Kabupaten Buton Utara adalah dengan cara sebagai berikut:

1. Upaya yang dilakukan oleh Dinas Kesehatan Kabupaten Buton Utara yaitu melakukan pemantauan terhadap produk-produk pangan dengan memberikan Nomor PIRT terhadap pelaku usaha yang telah memenuhi syarat dan sebelumnya telah mendapat 
penyuluhan tentang produk makanan yang boleh untuk diedarkan, pengawasan terhadap pelaku usaha atas produk makanan yang menagandung zat pewarna tekstil, dan memberikan peringatan serta penarikan produk yang positif mengandung zat pewarna tekstil.

2. Upaya yang dilakukan oleh Dinas Kesehatan Kabupaten Buton Utara yaitu bekerjasama dengan instansi pemerintah dan Lembaga Konsumen Kabupaten Buton Utara untuk melakukan pengawasan, penyuluhan, sampling dan pengujian produk. Pelaku usaha yang terbukti melakukan pelanggaran dilaporkan kepada Dinas Kesehatan Kabupaten Buton Utara untuk ditindaklanjuti.

3. Upaya yang dilakukan Dinas Perindustrian dan Koperasi Kabupaten Buton Utara adalah dengan mengadakan penyuluahan tentang makanan yang aman dari zat berbahaya dan menfasilitasi pengaduan konsumen yang terdapat dalam Badan Penyelesaian Sengketa Konsumen (BPSK) untuk diselesaikan dengan pihak produsen yang telah diadukan.

4. Upaya yang dilakukan Lembaga Konsumen Kabupaten Buton Utara adalah dengan melakukan pendidikan bagi konsumen agar lebih kritis dan teliti terhadap produk makanan yang akan dikonsumsi, membantu konsumen dalam memperjuangkan haknya termasuk menerima keluhan ataupun pengaduan konsumen, dan melakukan pengawasan bersama instansi pemerintah.

2. Perlindungan Hak Konsumen Atas Keamanan Dalam Mengkonsumsi Makanan Yang Mengandung Zat Pewarna Tekstil Tidak Sesuai Dengan Undang-Undang Nomor 8 Tahun 1999 tentang Perlindungan Konsumen 
Pelaksanaan pengawasan hak konsumen atas informasi dilakukan terhadap label pangan industri pangan rumah tangga, label dianggap sebagai sumber informasi bagi konsumen. Dinas Kesehatan Kabupaten Buton Utara melakukan pengawasan label pangan industri rumah tangga secara periodik yaitu pada waktu menjelang hari besar keagamaan (idhul fitri, natal, dan tahun baru), pengawasan dilakukan melalui operasi ke pasar tradisional, toko, mini market dan penjual pangan jajanan di sekolah.

Berdasarkan hasil penelitian penulis masih ditemukan produk pangan industri rumah tangga belum sepenuhnya memenuhi persyaratan label sebagai sumber informasi bagi konsumen karena produk pangan industri rumah tangga di Kabupaten Buton Utara, label produk pangan yang tidak memenuhi persyaratan termasuk label tidak menggunakan masa kadaluarsa, umur simpan atau waktu kadaluarsa merupakan suatu rentang waktu yang menyatakan bahwa produk masih dalam keadaan aman dikonsumsi tetap memenuhi sifat sensoris, kimia, fisik dan mikrobiologis sesuai dengan pernyataan nilai gizi yang tercantum pada label. Sedangkan alamat produksi dalam label penting digunakan untuk memudahkan pengawasan produk pangan industri rumah tangga di Kabupaten Buton Utara karena dengan adanya alamat produksinya Dinas Kesehatan Kabupaten Buton Utara mudah untuk melacak lokasi produk tersebut apabila hasil produksinya tidak sesuai dengan ketentuan yang telah diatur.

Pasal 4 (c) Undang-Undang Nomor 8 Tahun 1999 tentang Perlindungan Konsumen telah diatur hak atas informasi yang benar, jelas, dan jujur mengenai kondisi dan jaminan barangdan/atau jasa, salah satu sumber informasi adalah label dimana konsumen dapat memperoleh informasi yang benar, jelas dan lengkap dari segi kuantitas, isi, kualitas baik masa kadaluarsa ataupun komposisi bahan yang digunakan. 
Berbagai pelanggaran pelabelan pangan disebabkan oleh :

1. Pelaku usaha tidak mengetahui kewajiban berdasarkan undang-undang perlindungan konsumen

2. Kurangnya sosialisasi dari pemerintah terkait (dinas kesehatan, lembaga perlindungan konsumen)

3. Konsumen tidak memperhatikan kemasan produk pangan.

Pelanggaran tentang informasi pelabelan dapat dikenai sanksi paling ringan berupa tindakan administratif (teguran tertulis), denda hingga Rp 50.000.000 (lima puluh juta), dan bahkan sampai pencabutan ijin usaha. Hal tersebut diatur pada pasal 21 Undang-undang Nomor 69 tahun 1999 tentang Label dan Iklan Pangan.

Berdasarkan pasal 8 ayat 1 Undang-Undang Nomor 8 Tahun 1999 tentang Perlindungan Konsumen mengatur tentang larang pelaku usaha tidak memenuhi atau tidak standar yang dipersyaratkan dan ketentuan peraturan perundang-undangan. Dalam hal keamanan pangan yang dapat dilihat dari sampel pangan yang diuji menunjukan bahwa pelaku usaha melakukan perbuatan melawan hukum. Di Kabupaten Buton Utara yang tidak memperhatikan keamanan pangan menurut ibu Chusnul Arifianti selaku kepala bidang farmasi makanan yang dilakukan oleh produsenya itu penarikan terhadap produk pangan industri rumah tangga yang beredar di pasar.

Selain itu yang perlu diperhatikan adalah kesadaran dari masyarakat sebagai konsumen karena Selama ini belum ada laporan dari masyarakat yang diterima Dinas Kesehatan Kabupaten Buton Utara mengenai kerugian akibat mengkonsumsi pangan industri rumah tangga yang mengandung bahan kimia berbahaya, hal tersebut penting karena hak dan kewajiban antara pelaku usaha dan konsumen saling berhubungan 
timbal balik. Pasal 19 ayat 1 Undang-Undang Nomor 8 Tahun 1999 tentang perlindungan konsumen menyatakan bahwa yaitu pelaku usaha bertanggungjawab dalam hal memberikan ganti kerugiaan kerusakan, pencemaran, dan atau kerugian konsumen akibat mengkonsumsi barang dan atau jasa yang dihasilkan atau di perdagangkan. Ganti kerugian yang dimaksud merupakan pengembalian

Dari hasil penelitian penulis di Kabupaten Buton Utara maka terdapat penemuan yang sangat memprihatinkan bahwa pemerintah terkait ketika mendapatkan temuan ataupun mengetahui mengenai pedagang yang menyalahi aturan hal tersebut terkesan kurang dipublikasikan, sehingga kedudukan konsumen disini kurang seimbang dalam artian konsumen belum dilindungi haknya sepenuhnya atas keterbukaan informasi produk makanan yang dikonsumsi.

Padahal Undang-Undang Nomor 8 Tahun 1999 tentang Perlindungan Konsumen telah secara tegas menyebutkan mengenai hak konsumen dalam Pasal 4. Alasan kurang sesuainya perlindungan hak konsumen atas informasi dan keamanan dalam mengkonsumsi makanan yang mengandung zat pewarna tekstil rodhamin B dengan Undang-Undang Nomor 8 Tahun 1999 tentang Perlindungan Konsumen adalah karena pemerintah dalam memenuhi hak konsumen atas informasi yang benar, jelas, dan jujur mengenai kondisi dan jaminan barang dan/atau jasa pemerintah Kabupaten Buton Utara tidak memberikan informasi kepada masyarakat tentang penemuan pemerintah Kabupaten Buton Utara atas pelaku usaha yang telah memproduksi makanan yang mengandung zat pewarna tekstil.

Sehingga penulis sangat mengharapkan agar tetap ada kesadaran dan perlunya pelaku usaha maupun konsumen yang cerdas dalam menggunakan produk ataupun 
mengkonsumsi makanan olahan yang terdapat baik di toko maupun dipasar tradisional seperti di Pasar Minang-Minanga Kabupaten Buton Utara. Demi terlindunginya keselamatan, kesehatan, serta kenyamanan,bagi seluruh pihak.

\section{Faktor Penghambat Bagi Pemerintah Kabupaten Buton Utara dan Lembaga Konsumen Kabupaten Buton Utara Untuk Mengatasi Beredarnya Makanan Yang Mengandung Zat Pewarna Tekstil}

Ada beberapa faktor penghambat yang ditemui dalam penelitian ini yaitu 1. Pelaku Usaha Tidak Mengetahui Kewajibannya Berdasarkan Undang-Undang

Perlindungan Konsumen

Adanya hukum dan menajemen pendekatan sistem pengaturan informasi pangan industri rumah tangga mulai dari pemerintah kepada pelaku usaha, penegakan hukum dan sebagainya yang digerakkan dalam satu mekanisme yang terstruktur. Pelaku usaha yang menyalahi aturan dengan mengesampingkan hak konsumen memiliki tujuan memperoleh keuntungan yang sebesar-besarnya sehingga tidak mau mengikuti ketentuan yang berlaku karena para pelaku usahan memandang akan menambah biaya produksi karena dengan melengkapi kemasan pangan indutri rumah tangga dengan label yang lengkap dinilai membutuhkan teknologi tambahan dan bahan kemasan yang tentunya pelaku usaha mengeluarkan biaya produksi dan dinilai membebani pelaku usaha.

Selain itu pelaku usaha kurang mengetahui ketentuan yang mengatur pada label pangan industri rumah tangga sebagai sumber informasi konsumen untuk mengetahui kondisi barang, hal ini diakibatkan oleh sumber daya manusia yang belum memadai dari 
pelaku usaha industri rumah tangga yang diakibatkan oleh rendahnya tingkat pendidikan dari pelaku usaha itu sendiri.

2. Konsumen Tidak Mengetahui Haknya Berdasarkan Undang-Undang Perlindungan Konsumen

Dinas Kesehatan Kabupaten Buton Utara dalam melaksanakan tugas dalam pengawasan terhadap hak konsumen atas informasi dan keamanan dalam mengkonsumsi pangan sering tidak maksimal akibat keterbatasan anggaran dana. Padahal program kerja Dinas Kesehatan membutuhkan dana yang tidak sedikit. Dana tersebut di alokasikan untuk:

a) Dana untuk melakukan koordinasi dengan instansi lain yang berwenang.

b) Dana untuk program penyuluhan produsen dan konsumen.

c) Dana untuk uji biaya laboratorium uji sampel pangan industri rumah tangga.

\section{PENUTUP}

Pengawasan hak konsumen atas keamanan dalam mengkonsumsi makanan pangan industri rumah tangga berdasarkan Undang -Undang Nomor 8 Tahun 1999 tentang Perlindungan Konsumen yang dilakukan oleh instansi pemerintah dan lembaga lainnya adalah dengan cara sebagai berikut yakni dengan upaya yang dilakukan oleh Dinas Kesehatan Kabupaten Buton Utara yaitu melakukan pemantauan terhadap produkproduk pangan dengan memberikan Nomor PIRT terhadap pelaku usaha yang telah memenuhi syarat dan sebelumnya telah mendapat penyuluhan tentang produk makanan yang boleh untuk diedarkan, pengawasan terhadap pelaku usaha atas produk makanan yang menagandung zat pewarna tekstil Kabupaten Buton Utara, dan memberikan peringatan serta penarikan produk yang positif mengandung zat pewarna tekstil. Upaya 
yang dilakukan oleh Balai POM Kabupaten Buton Utara yaitu bekerjasama dengan instansi pemerintah dan Lembaga Konsumen Kabupaten Buton Utara untuk melakukan pengawasan, penyuluhan, sampling dan pengujian produk. Pelaku usaha yang terbukti melakukan pelanggaran dilaporkan kepada Dinas Kesehatan Kabupaten Buton Utara untuk ditindaklanjuti. Faktor penghambat bagi Pemerintah dan Lembaga Konsumen Kabupaten Buton Utara dalam mengatasi beredarnya makanan yang mengandung zat pewarna tekstil yaitu keterbatasan anggaran untuk menyelenggarakan kegiatan yang telah diagendakan sehingga ada kegiatan yang tidak terlaksana, sistem birokrasi yang masih berbelit-belit sehingga tindak lanjut terhadap pelaku usaha

\section{DAFTAR PUSTAKA}

Agus Salim. 2006. Metodologi Penelitian Kualitatif, Teori Paradigma Penelitian Sosial, Tiara Wacana, Bandung.

Adi,Rianto, Metodologi Penelitian Sosial dan Hukum, Jakarta: Granit, 2004.

Bambang Prasetyo dan Lina Miftahul Jannah, Metode Penelitian Kuantitatif: Teori dan Aplikasi, Rajawali Pers, cetakan pertama tahun 2005

Barkatullah, Abdul Halim, Hak -hak Konsumen, Bandung: Nusamed Studio, 2010.

Burhanuddin, Pemikiran Hukum Perlindungan Konsumen dan Sertifikasi Halal, Malang: UIN-Maliki Press, 2011.

Fuady, Munir, Pengantar Hukum Bisnis, Jakarta: PT. Citra Aditya Bakti, 2002.

Gerald, et al., Sistem pendekatan Kuantitatif, 1981.

Kartono DR. kartini. 1990. Pengantar metodologi riset sosial. Bandung: mandar maju Kristiyanti, Celina Tri Siwi, Hukum Perlindungan Konsumen, Jakarta: Sinar Grafika, 2009. Mertokusumo, Sudikno, Hukum Acara Perdata di Indonesia, Yogyakarta: Liberty, 1982. Nazir mohammad.1988. Metode Penelitian. Jakarta: Ghalia

SugiyoNomor 2009. Metode Penelitian Kuantitatif dan Kualitatif dan $R \& D$, Alfabeta, Bandung

Miru, Ahmadi dan Sutarman Yodo, Hukum-hukum Perlindungan Konsumen, Jakarta: PT. Raja Grafindo Persada, 2005

\section{Peraturan Perundang-Undangan:}

Undang-Undang Nomor 8 Tahun 1999 tentang Perlindungan Konsumen

Undang-Undang Nomor 18 Tahun 2012 tentang Pangan

Undang-Undang Nomor 36 Tahun 2009 tentang Kesehatan

Peraturan Pemerintah Nomor 69 Tahun 1999 tentang Label dan Iklan Pangan 